\title{
Development and Evaluation of a Global Burnout Index Derived from the Use of the Copenhagen Burnout Inventory in Portuguese Physicians
}

\author{
Desenvolvimento e Avaliação de um Índice Global de \\ Burnout a Partir da Aplicação do Inventário de Burnout \\ de Copenhaga em Médicos Portugueses
}

\author{
Teresa LAPA $\triangle^{1,2}$, Sérgio CARVALHO ${ }^{3}$, Joaquim VIANA ${ }^{1}$, Pedro Lopes FERREIRA ${ }^{4,5}$, José PINTO-GOUVEIA ${ }^{3}$, \\ Adriana Belo CABETE 6 \\ Acta Med Port 2018 Oct;31(10):534-541 - https://doi.org/10.20344/amp.10407
}

\section{ABSTRACT}

Introduction: The Copenhagen Burnout Inventory was developed to overcome what some authors have proposed as potential limitations of existing burnout measures. Specifically, the Copenhagen Burnout Inventory measures the main component of burnout (i.e. exhaustion) in three domains: personal-, work- and patient-related. Additionally, some authors have argued the necessity to have available a global burnout index.

Material and Methods: This study followed a cross-sectional design in a sample of Portuguese physicians $(n=1348)$. A confirmatory factor analyses was conducted and the Copenhagen Burnout Inventory's three-factor structure was tested. In addition, a model with a $2^{\text {nd }}$ order factor was tested with the goal of achieving a one-factor structure that would allow a global burnout index.

Results: The confirmatory factor analyses showed a good model fit for both the three-factor and one-factor model, having the latter a significant better fit. The Copenhagen Burnout Inventory showed good psychometric properties for both structures, with good reliability according to Chronbach's alphas and average variance extracted between factors. The Copenhagen Burnout Inventory I was statistically and positively correlated with depression, anxiety and stress symptoms, as well as rumination, and negatively correlated with life satisfaction.

Discussion: The current study shows that the Copenhagen Burnout Inventory is a psychometrically valid measure of burnout in Portuguese physicians, and contributes with an instrument able to produce a global index of burnout. This measure provides comprehensive information on different dimensions associated with the development of burnout, as well as presents a global burnout score. Results show that participants who had more burnout also presented higher levels of depressive, anxiety and stress symptoms, as well as present more ruminative thinking, and less life satisfaction.

Conclusion: The Copenhagen Burnout Inventory is a psychometrically valid measure of burnout that allows for exploratory studies on the overall level of exhaustion, thus making it possible the comparison between groups in a way that is not restricted to occupationspecific aspects.

Keywords: Anesthesiology; Burnout, Professional; Surveys and Questionnaire; Psychologic Stress

\section{RESUMO}

Introdução: O Inventário de Burnout de Copenhaga foi desenvolvido de forma a ultrapassar as limitações dos instrumentos de avaliação de burnout existentes. Especificamente, o Inventário de Burnout de Copenhaga mede o componente principal do burnout, a exaustão, em três domínios: pessoal, relacionado com o trabalho, e relacionado com o doente. Além disso, alguns autores têm sugerido a necessidade de um índice global de burnout.

Material e Métodos: Este estudo seguiu um desenho transversal em uma amostra de médicos portugueses $(n=1348)$. Os símbolos estatísticos aparecem a itálico. Foram realizadas análises fatoriais confirmatórias e a estrutura dos três fatores do Inventário de Burnout de Copenhaga foi testada. Adicionalmente, foi testado o ajustamento de um modelo com um fator de segunda ordem que permitisse medir um índice global de burnout.

Resultados: A análise fatorial confirmatória mostrou um bom ajustamento dos modelos, quer do modelo com três fatores, quer do modelo unifatorial, tendo o último um melhor ajustamento. O Inventário de Burnout de Copenhaga mostrou boas propriedades psicométricas para ambas as estruturas, com boa confiabilidade de acordo com os alfas de Cronbach e a variância extraída da média entre os fatores. O Inventário de Burnout de Copenhaga global correlaciona-se positivamente com a depressão, ansiedade, e sintomas de stress, assim como com a ruminação, e negativamente com a satisfação com a vida.

Discussão: O presente estudo apresenta resultados que sugere que o Inventário de Burnout de Copenhaga é uma medida válida de burnout nos médicos portugueses, contribuindo com um instrumento capaz de produzir um índice global de burnout. Este instrumento permite fornecer informação compreensiva sobre as diferentes dimensões associadas ao desenvolvimento de burnout, assim como apresentar um valor global do burnout. Os resultados mostraram que os participantes que apresentaram niveis mais elevados de burnout também têm mais sintomatologia depressiva, ansiosa e de stress, mais ruminação, e menos satisfação com a vida.

1. Anaesthesiology Service. Coimbra Hospital and University Centre. Coimbra. Portugal.

2. Faculty of Health Sciences. University of Beira Interior. Covilhã. Portugal.

3. Cognitive-Behavioural Research Centre. University of Coimbra. Coimbra. Portugal.

4. Faculty of Economics. University of Coimbra. Coimbra. Portugal.

5. Centre for Health Studies and Research. University of Coimbra. Coimbra. Portugal.

6. Department of Biostatistics. University of Coimbra. Coimbra. Portugal.

$\square$ Autor correspondente: Teresa Lapa. teresalapa@hotmail.com

Recebido: 14 de fevereiro de 2018 - Aceite: 20 de agosto de 2018 | Copyright @ Ordem dos Médicos 2018 
Conclusão: A existência de um índice global de burnout permite estudos exploratórios sobre o nível de exaustão global, possibilitando a sua comparação entre diferentes grupos de forma não circunscrita a aspetos específicos da profissão.

Palavras-chave: Anestesiologia; Esgotamento Profissional; Inquéritos e Questionários; Portugal; Stress Psicológico

\section{INTRODUCTION}

Burnout is common among physicians, and it can be a precursor of serious problems such as dissatisfaction with work, work-family conflicts, ${ }^{1}$ and suicidal ideation. ${ }^{2,3}$ It is worth noting that burnout impacts negatively not only in practitioner's performance, but also has strong impact on patients themselves, and yield an inherent burden on health care services. ${ }^{4}$ Portugal is not an exception, as studies have showed that Portuguese doctors present high levels of burnout. ${ }^{5}$

The importance of assessing burnout in physicians has long been recognized. The instrument most commonly used to evaluate burnout is the Maslach Burnout Inventory $(\mathrm{MBI}),{ }^{6}$ a three-factor questionnaire that assesses emotional exhaustion, depersonalization and low sense of personal accomplishment, which has become the gold standard metric of burnout. MBI has been used across a wide range of demographic and professional populations, although several criticisms have been raised concerning this instrument. Some authors have pointed out that MBI lacks balance, i.e. the three dimensions assessed are not weighted equally, and it lacks clarity between the three subscales. Specifically, high scores in exhaustion and depersonalization usually relate to low scores in personal accomplishment. ${ }^{7}$ Additionally, depersonalization has been considered a mechanism of coping with exhaustion, whilst personal accomplishment is a consequence of exhaustion, rather than a dimension of burnout itself. 7,8

In order to tackle these limitations, another measure of burnout was developed. The Copenhagen Burnout Inventory $(\mathrm{CBI})^{7}$ is an open source tool developed to assess burnout in a less complex manner. CBI differentiates three life domains from which emotional exhaustion may arise: personal, workrelated and patient-related. Personal burnout is the degree of physical and psychological exhaustion one can experience, unrelated to their occupation. Work-related burnout is the degree to which physical and psychological exhaustion is perceived in relation to their work. Client-related burnout is the level of exhaustion that stem from the professional relation with clients. ${ }^{7}$ In sum, $\mathrm{CBI}$ has been described as a more straightforward measure, ${ }^{9}$ with some advantages when compared to MBI. Namely, $\mathrm{CBI}$ assesses the same overall construct (burnout) in different contexts, as opposed to confounding burnout and its consequences in the same construct as $\mathrm{MBI}$ does - which could lead to erroneous interpretation of its results.

Additionally, there has been in the last years the interest of developing overall indices of burnout. ${ }^{10}$ Although this was tried with $\mathrm{CBI}$ in a sample of teachers, ${ }^{11}$ this has never been tested in a robust statistical procedure. Using $\mathrm{CBI}$ as a total score, without testing its fitness and psychometric validity, yields potential inaccurate interpretation of results. The main purpose of our study is to test the factor structure and psychometric properties (concurrent and divergent validity) of $\mathrm{CBI}$ in Portuguese physicians, as well as to develop and assess a global index of burnout. This is a part of a larger study that explores different factors and consequences related to burnout in Portuguese anesthesiologists.

\section{MATERIAL AND METHODS \\ Participants}

The total sample was composed of 1348 Portuguese physicians of different specialties from public and private hospitals.

\section{Study design}

With the approval of the Ethics Committee (Faculty of Health Sciences, University of Beira Interior) and participant informed consent, an anonymous paper survey was conducted in Portuguese physicians from different medical specialties.

\section{Instruments}

The Copenhagen Burnout Inventory (CBI) was developed by Kristensen et $a^{\Gamma}$ and considers fatigue and exhaustion as core constructs. This 19-item questionnaire measures three burnout sub-dimensions: personal burnout (6 items), work-related burnout (7 items), and client-related burnout (6 items). It was translated into Portuguese and validated to Portuguese nurses by Cesaltino Fonte. ${ }^{12}$ The original version presented a good internal consistency for all three subscales: personal burnout $(\alpha=0.87)$, workrelated burnout $(\alpha=0.87$ ), and client-related burnout ( $\alpha$ $=0.85)$. In the Portuguese version, the Cronbach's alpha coefficient observed in three scales $(0.845,0.866$ and 0.843 respectively) indicated that the instrument has a good internal consistency.

Depression, Anxiety and Stress Scales (DASS-21), was developed by Lovibond and Lovibond ${ }^{13}$ with a Portuguese version by Pais-Ribeiro, Honrado and Leal. ${ }^{14}$ It is a selfreported scale with 21 items with three subscales which aim to measure symptoms of depression, anxiety and stress. Originally, the authors found that all subscales had adequate to good internal consistency with alpha's values of 0.81 for depression 0.73 for anxiety and 0.81 for stress.

Satisfaction With Life Scale (SWLS), developed by Diener ${ }^{15}$ and adapted to Portuguese by Simões, ${ }^{16}$ is a 5 -item scale designed to measure global cognitive judgements of tife satisfaction. It shows good convergent validity with other scales and with other types of assessments of subjective well-being. The original version found good internal consistency of the scale (Chronbach alpha's between 0.61 and 0.81 ). The Portuguese version study found a good internal consistency $(\alpha=0.77)$.

Sheehan Disability Scale (SDS), described by Sheehan ${ }^{17}$ and translated to Portuguese by Pinto-Gouveia ${ }^{18}$ includes three self-rated items designed to measure to what 
degree work, social life, and family life are impaired by current psychiatric symptoms (e.g., panic, anxiety, phobia, or depression). Each item includes an 11-point analogue scale using visual-spatial, numeric and verbal descriptive markers simultaneously to represent the level of disruption. This is a brief measure of impairment in functioning widely used in mental health research and practice.

Ruminative Response Scale (RRS-10) was developed by Treynor, Gonzalez and Nolen-Hoeksema ${ }^{19}$ - Portuguese version by Dinis et al. ${ }^{20}$ This 10 -item instrument assesses rumination, a self-focused psychological process that involves repetitive thinking on personal negative feelings, as well as a pattern of self-reflection on the events that have led to these feelings and/or its consequences. ${ }^{21}$ The internal consistency of the original scale was $\alpha=0.85$ for the total scale. It is generally accepted that rumination is an important psychological process related to depression, ${ }^{21}$ thus being a relevant variable in a burnout study such as ours.

\section{Procedure}

Reliability of $\mathrm{CBI}$ was obtained by computing Cronbach's $\alpha$. Construct validity was tested by comparing burnout scores with known socio-demographic groups. Criteria validity was assessed via correlation with different measures. Discriminant validity was assessed comparing average variance extracted (AVE) of each factor with the shared variance between factors. The AVE of two factors both need to be larger than their shared variance. ${ }^{22}$

With approval by Ethics Committee and participant informed consent, an anonymous paper survey was conducted in Portuguese physicians from different medical specialties.

\section{Analytical plan}

Z-scores $(|Z|>3)$ determined univariate outliers and multivariate outliers considered through Mahalanobis distance $\left(D^{2}<0.0010\right)$. Normality was assessed by coefficients of skewness (Sk) and Kurtosis (Ku). For each of the three burnout dimensions, where participants missed fewer than three items, these missing items were imputed based upon their scores for the other dimension items. Individuals who had three or more items missing for the same dimension, were excluded from further analysis. At the end, six participants were excluded from our sample given the aforementioned criteria.

Correlations between $\mathrm{CBI}$ and other scales, such as DASS-21, SDS, rumination and SWLS were evaluated by the estimation of Pearson correlation coefficients and intraclass correlation coefficient.
Factor structure was evaluated by confirmatory factor analysis (CFA) and covariance matrices were used to analyze the measurement models. Model fit was assessed by maximum likelihood estimation and goodness of fit was evaluated with root-mean-square error of approximation (RMSEA), chi-square $\left(\chi^{2}\right)$, normed chi-square $\left(\chi^{2} / \mathrm{df}\right)$, Comparative Fit Index (CFI), Incremental Fit Index (IFI) and Standardized Root Mean Square Residual (SRMR). When RMSEA, one of the most informative fit indices ${ }^{23}$ lies between 0.05 and 0.08 , the fit is considered reasonable. It is also considered reasonable when Normed chi-square values lies between 2 and $5^{24,25}$ and $\mathrm{CFI}$ and IFI are greater than 0.90 . For SRMR, a value less than 0.10 and of 0.08 (in a more conservative view) are considered a good fit. ${ }^{26}$

To improve the goodness of fit, items with factor loadings lower than 0.4 , or with modification indexes (MI) for model fit improvement greater than $11(p<0.001)$ were removed from the model. ${ }^{10}$ The adjustment of the model took the MI into consideration. The chi-square test was used to test whether two different models were significantly different, one where it was only considered information regarding the amount of observed variables' variance explained by the underlying latent variable factor (Model 1); and the other correlated errors (Model 2), were also considered.

For continuous variables, means were compared between three or more groups considering ANOVA with F test or Welch test. The last one was used when the null hypothesis of variances homogeneity was rejected by Levene's test. When means were compared between two groups, $t$ test was used instead.

SPSS software was used to implement all the descriptive and correlational procedures, and AMOS software was used to conduct CFA, considering structural equation modeling (SEM).

Reliability of $\mathrm{CBI}$ was obtained by computing Cronbach's $\alpha$. Construct validity was tested by comparing burnout scores with known socio-demographic groups. Criteria validity was assessed via correlation with different measures. Discriminant validity was assessed comparing average variance extracted (AVE) of each factor with the shared variance between factors. The AVE of two factors need both to be larger than their shared variance. ${ }^{22}$

\section{RESULTS}

Results from statistical analyses on normality showed there were no severe violations of normality.

\section{Demographic data}

The 1348 respondents had a mean age of 45.39 years $(S D=10.93)$ and $41.9 \%$ were more than 50 years old.

Table 1 - Confirmatory factor analyses $(n=1348)$

\begin{tabular}{|c|c|c|c|c|c|c|c|c|}
\hline & $\chi^{2}$ & $\mathrm{df}$ & $p$ value & $\mathrm{NC}$ & CFI & IFI & RMSEA & SRMR \\
\hline Model 1. 3-factor CBI & 1906.925 & 149 & $<0.001$ & 12.798 & 0.879 & 0.879 & 0.094 & 0.058 \\
\hline Model 2. Correlated errors & 649.486 & 134 & $<0,001$ & 4.847 & 0.965 & 0.965 & 0.053 & 0.044 \\
\hline Model 3. $2^{\text {nd }}$ order & 618.766 & 131 & $<0.001$ & 4.652 & 0.967 & 0.967 & 0.052 & 0.043 \\
\hline
\end{tabular}

NC: Normed chi-square ( $\left.\chi^{2} / \mathrm{df}\right)$; CFI: Comparative fit index; IFI: Iterative fit index; RMSEA: Root mean square error of approximation; SRMR: Standardised root mean residual; df: Degrees of freedom 
Table 2 - Correlations between $\mathrm{CBI}$ and other constructs

\begin{tabular}{|c|c|c|c|c|c|c|c|c|c|}
\hline & \multirow{2}{*}{$\begin{array}{l}\text { Measure } \\
\text { - Stress } \\
\text { - Depression } \\
\text { - Anxiety }\end{array}$} & \multicolumn{2}{|c|}{$\begin{array}{l}\text { Personal } \\
\text { Burnout }\end{array}$} & \multicolumn{2}{|c|}{$\begin{array}{c}\text { Work } \\
\text { Burnout }\end{array}$} & \multicolumn{2}{|c|}{$\begin{array}{l}\text { Patient } \\
\text { Burnout }\end{array}$} & \multicolumn{2}{|c|}{$\begin{array}{l}\text { Global } \\
\text { Burnout }\end{array}$} \\
\hline DASS21 & & $\begin{array}{l}0.485 \\
0.482 \\
0.385\end{array}$ & $\begin{array}{l}<0.001 \\
<0.001 \\
<0.001\end{array}$ & $\begin{array}{l}0.496 \\
0.503 \\
0.385\end{array}$ & $\begin{array}{l}<0.001 \\
<0.001 \\
<0.001\end{array}$ & $\begin{array}{l}0.324 \\
0.371 \\
0.284\end{array}$ & $\begin{array}{l}<0.001 \\
<0.001 \\
<0.001\end{array}$ & $\begin{array}{l}0.499 \\
0.519 \\
0.403\end{array}$ & $\begin{array}{l}<0.001 \\
<0.001 \\
<0.001\end{array}$ \\
\hline SDS & $\begin{array}{l}\text { - work } \\
\text { - social life } \\
\text { - affective life }\end{array}$ & $\begin{array}{l}0.491 \\
0.561 \\
0.552\end{array}$ & $\begin{array}{l}<0.001 \\
<0.001 \\
<0.001\end{array}$ & $\begin{array}{l}0.538 \\
0.586 \\
0.588\end{array}$ & $\begin{array}{l}<0.001 \\
<0.001 \\
<0.001\end{array}$ & $\begin{array}{l}0.358 \\
0.331 \\
0.349\end{array}$ & $\begin{array}{l}<0.001 \\
<0.001 \\
<0.001\end{array}$ & $\begin{array}{l}0.532 \\
0.566 \\
0.571\end{array}$ & $\begin{array}{l}<0.001 \\
<0.001 \\
<0.001\end{array}$ \\
\hline \multicolumn{2}{|c|}{ RRS - rumination } & 0.428 & $<0.001$ & 0.406 & $<0.001$ & 0.248 & $<0.001$ & 0.412 & $<0.001$ \\
\hline \multicolumn{2}{|l|}{ SWLS } & -0.386 & $<0.001$ & -0.442 & $<0.001$ & -0.354 & $<0.001$ & -0.454 & $<0.001$ \\
\hline \multicolumn{2}{|c|}{ Personal burnout } & 1 & & 0.814 & $<0.001$ & 0.474 & $<0.001$ & 0.868 & $<0.001$ \\
\hline \multicolumn{2}{|c|}{ Work burnout } & 0.814 & $<0.001$ & 1 & & 0.616 & $<0.001$ & 0.934 & $<0.001$ \\
\hline \multicolumn{2}{|c|}{ Patient burnout } & 0.474 & $<0.001$ & 0.616 & $<0.001$ & 1 & 1 & 0.807 & $<0.001$ \\
\hline
\end{tabular}

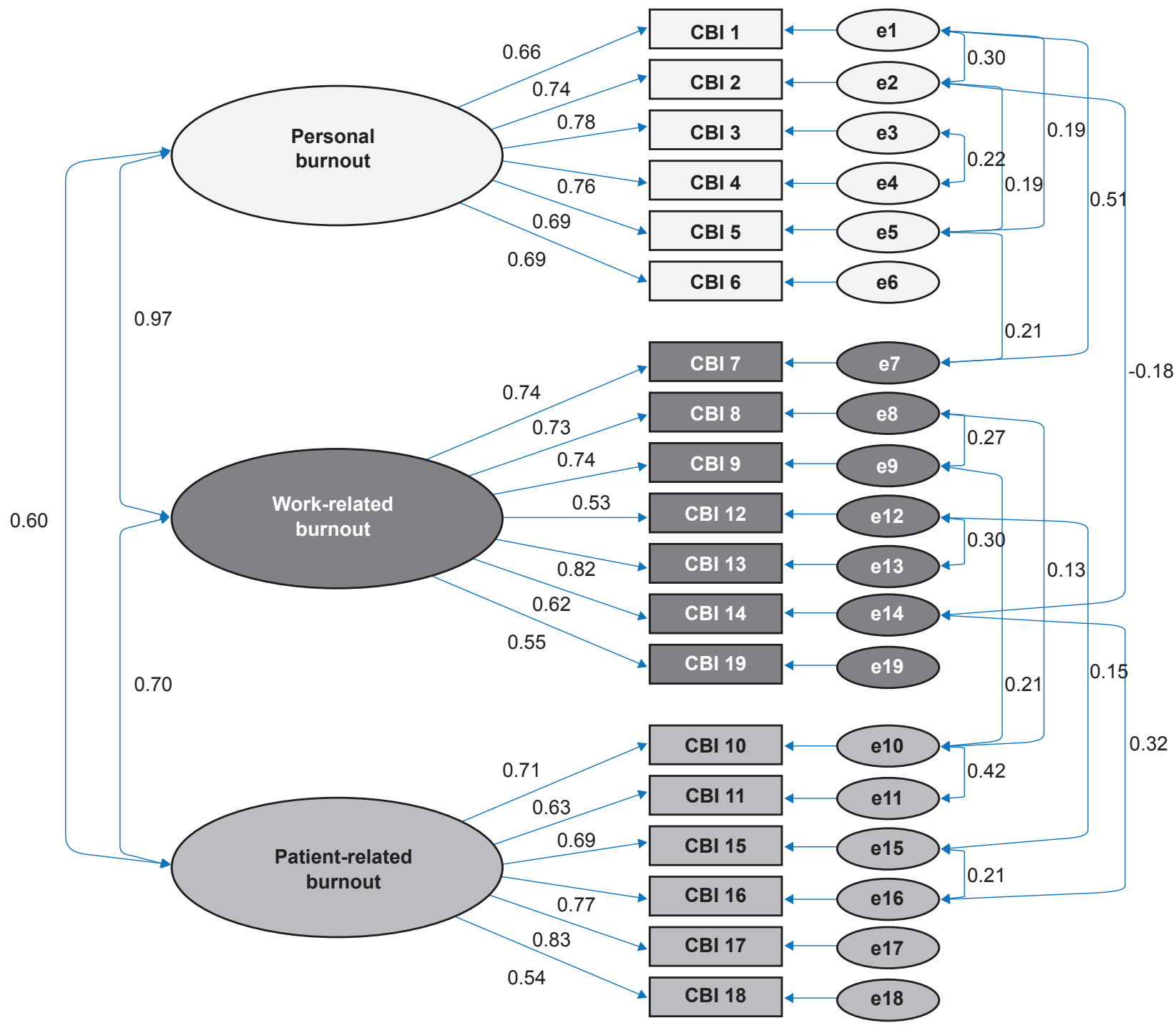

Figure 1 - Model 2 - Physician burnout as a 3-factor model $\chi^{2}(134)=649.49 ; p<0.001 ; \mathrm{NC}\left(\chi^{2} / \mathrm{df}\right)=4.85 ; \mathrm{CFI}=0.97 ; \mathrm{IFI}=0.97 ; \mathrm{RMSEA}=0.05 ; \mathrm{SRMR}=0.04$ 
From the total sample $62.5 \%$ were female, $57.2 \%$ worked exclusively in the public sector and the majority had more than 11 years of work experience $(55.9 \%)$ with a weekly workload between 40 to 60 hours (55.6\%).

\section{Confirmatory factor analysis}

A 3-factor model was computed (Model 1) in order to test its factor structure.

Model 1 presented poor model fit, according to model fit indices. CFI and IFI did not reach the suggested cut-off value $0.90 .{ }^{10}$ Model 1 presented an RMSEA greater than 0.08 and a SRMR higher than 0.05 , which also suggest a poor fit of the model (see Table 1).

A second model (Model 2) was also considered, based on the first model's Modification Indices (MI). Considering the MI's values, it seemed appropriate to test a new model in which items' errors are correlated. On Personal Burnout factor, the following pairs of items share variance: $\mathrm{CBI} 1$ and $\mathrm{CBI} 2, \mathrm{CBI} 3$ and $\mathrm{CBI} 4, \mathrm{CBI} 1$ and $\mathrm{CBI}$, $\mathrm{CBI} 2$ and $\mathrm{CBI} 5$; on Work Burnout factor the following pairs of items share variance $\mathrm{CBI} 8$ and $\mathrm{CBI}, \mathrm{CBI} 12$ and $\mathrm{CBI} 13$; on Patient Burnout factor the following pairs of items share variance CBI10 and CBI11, CBI15 and CBI16. It seems that the errors associated to the following pairs of items $\mathrm{CBI} 1$ and CBI7, CBI2 and CBI14, CBI5 and CBI7, CBI8 and CBI10, $\mathrm{CBI} 9$ and $\mathrm{CBI} 10, \mathrm{CBI} 12$ and $\mathrm{CBI} 15, \mathrm{CBI} 14$ and $\mathrm{CBI} 16$. In fact, this model showed a better fit, as described in Table 2. The normed chi-square was lower than the value observed for Model 1, but it was still above 2; CFI and IFI were both higher than 0.90; RMSEA showed a better fit (lower than 0.08); SRMR also confirmed a better model fit, as SRMR was lower than 0.05 . Model 2 was significantly better than Model 1 (DIFFTEST; $\left.\Delta \chi^{2}=1257.439, \mathrm{df}=15\right)$ (Fig. 1).

After that, we tested a third model in which a global latent ( $2^{\text {nd }}$ order) factor was tested. The rationale behind this structure follows the clinical necessity to have an overall global burnout index, which the three-factor structure does not provide. Thus, a third model (Model 3 ) with a latent $2^{\text {nd }}$

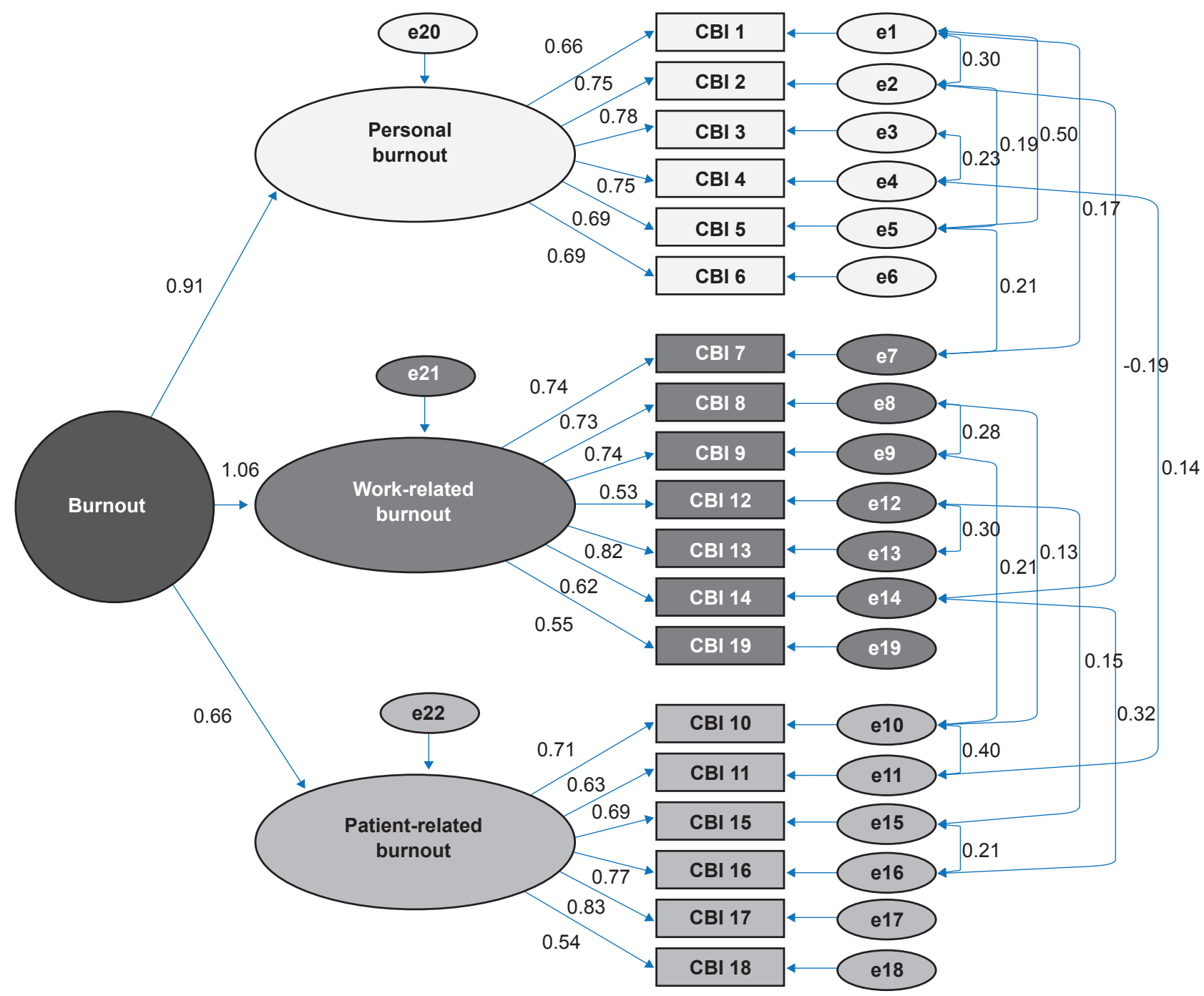

Figure 2 - Model 3 - Physician burnout as a $2^{\text {nd }}$ order factor

$\chi^{2}(133)=618.77 ; p<0.001 ; \mathrm{NC}\left(\chi^{2} / \mathrm{df}\right)=4.65 ; \mathrm{CFI}=0.97 ; \mathrm{IFI}=0.97 ; \mathrm{RMSEA}=0.05 ; \mathrm{SRMR}=0.04$ 
order factor ('Burnout') was computed. Model 3 presented better model fit indices than Model 2 (see Table 1) and this improvement in fit was statistically significant (DIFFTEST; $\Delta \chi^{2}=30.720, \mathrm{df}=3$ ) (Fig. 2).

\section{Reliability analyses}

Results suggested reasonable composite reliability since Cronbach's a was 0.88 for Personal dimension, 0.86 for Work dimension, and 0.85 for Patient dimension. For global burnout index, Cronbach's $\alpha$ is 0.905 .

The calculated AVE was 0.52 for Personal, 0.48 for Work, and 0.49 for Patient, and it provided a measure of individual item reliability. Discriminant validity was assessed by comparing AVE and the square of correlation $\left(r^{2}\right)$ between factors. Good discriminant validity was obtained between Work and Patient $\left(r^{2}=0.49\right)$, and between Personal and Patient $\left(r^{2}=0.36\right)$, but not between Personal and Work $\left(r^{2}=\right.$ 0.94).

\section{Criterion validity}

Table 2 shows the correlations between the $\mathrm{CBI}$ and other study measures, considering our total sample $(\mathrm{n}=$ 1348).

The three subscales of $\mathrm{CBI}$ correlated positively with the three dimensions of SDS scale, stress, depression and anxiety, and rumination. On the other hand, it correlates negatively with life satisfaction. These results indicate that the $\mathrm{CBI}$ has good construct validity. Similarly, the total scale (global burnout index) is significantly correlated with all variables in the expected direction.

\section{Differences in $\mathrm{CBI}$ according to gender, age, specialty, years of experience, and institution}

In order to investigate whether burnout differs among known groups, we explored differences in $\mathrm{CBI}$ according to gender, age groups, specialists/residents, years of experience as a specialist and setting of practice (Table 3).

Table 3 - CBI differences among known groups

\begin{tabular}{|c|c|c|c|c|c|c|c|c|}
\hline \multirow[t]{2}{*}{ Demographics } & \multicolumn{2}{|c|}{$\begin{array}{l}\text { Personal } \\
\text { Burnout }\end{array}$} & \multicolumn{2}{|c|}{$\begin{array}{l}\text { Work-related } \\
\text { Burnout }\end{array}$} & \multicolumn{2}{|c|}{$\begin{array}{l}\text { Patient-related } \\
\text { Burnout }\end{array}$} & \multicolumn{2}{|c|}{$\begin{array}{l}\text { Global } \\
\text { Burnout }\end{array}$} \\
\hline & Mean (SD) & $p$ & Mean (SD) & $p$ & Mean (SD) & $p$ & Mean (SD) & $p$ \\
\hline \multicolumn{9}{|l|}{ Gender } \\
\hline Male $(n=504)$ & $41.9(17.0)$ & \multirow{2}{*}{$<0.001$} & $38.4(17.4)$ & \multirow{2}{*}{$<0.001$} & $26.7(19.2)$ & \multirow{2}{*}{0.018} & $35.8(15.8)$ & \multirow{2}{*}{0.001} \\
\hline Female $(n=841)$ & $48.6(16.8)$ & & $42.5(17.2)$ & & $24.1(19.1)$ & & $38.6(15.4)$ & \\
\hline \multicolumn{9}{|l|}{ Age (years) } \\
\hline$<40(n=490)$ & $47.9(16.8)$ & \multirow{3}{*}{$<0.001$} & $42.4(16.5)$ & \multirow{3}{*}{0.004} & $26.1(19.3)$ & \multirow{3}{*}{0.197} & $39.0(15.0)$ & \multirow{3}{*}{0.002} \\
\hline $40-49(n=293)$ & $47.6(16.2)$ & & $42.1(16.9)$ & & $25.3(19.6)$ & & $38.5(15.1)$ & \\
\hline$\geq 50(n=564)$ & $43.6(17.8)$ & & $39.1(18.3)$ & & $24.0(18.8)$ & & $35.8(16.2)$ & \\
\hline \multicolumn{9}{|l|}{ Region } \\
\hline North $(n=281)$ & $45.4(18.3)$ & \multirow{4}{*}{0.803} & $40.9(17.2)$ & \multirow{4}{*}{0.152} & $25.7(19.1)$ & \multirow{4}{*}{0.071} & $37.5(15.7)$ & \multirow{4}{*}{0.226} \\
\hline Centre $(n=662)$ & $46.5(16.7)$ & & $41.1(17.4)$ & & $25.8(20.0)$ & & $37.9(15.7)$ & \\
\hline South $(n=343)$ & $45.7(17.8)$ & & $41.1(17.8)$ & & $23.3(18.2)$ & & $36.9(15.7)$ & \\
\hline Islands $(n=47)$ & $45.4(12.7)$ & & $36.5(13.0)$ & & $21.4(14.7)$ & & $34.5(10.9)$ & \\
\hline \multicolumn{9}{|l|}{ Institution } \\
\hline Only Public $(n=770)$ & $47.0(17.2)$ & \multirow{3}{*}{0.035} & $41.8(17.4)$ & \multirow{3}{*}{0.074} & $25.1(19.3)$ & \multirow{3}{*}{0.915} & $38.2(15.6)$ & \multirow{3}{*}{0.172} \\
\hline Public + Priv $(n=514)$ & $44.5(17.0)$ & & $39.5(16.9)$ & & $25.0(19.1)$ & & $36.5(15.3)$ & \\
\hline Only Private $(n=62)$ & $46.3(18.4)$ & & $41.6(20.8)$ & & $24.1(19.1)$ & & $37.6(17.0)$ & \\
\hline \multicolumn{9}{|l|}{ Experience (years) } \\
\hline Intern $(n=111)$ & $50.2(18.7)$ & \multirow{6}{*}{0.001} & $42.9(16.3)$ & \multirow{6}{*}{0.048} & $22.7(16.9)$ & \multirow{6}{*}{0.105} & $38.9(13.9)$ & \multirow{6}{*}{0.036} \\
\hline$\leq 3(n=150)$ & $46.4(15.7)$ & & $42.4(16.1)$ & & $27.7(19.8)$ & & $39.0(14.5)$ & \\
\hline $4-5(n=131)$ & $46.9(16.4)$ & & $42.2(16.9)$ & & $27.8(20.1)$ & & $39.1(15.3)$ & \\
\hline $6-10(n=202)$ & $48.3(15.1)$ & & $42.8(15.9)$ & & $25.8(19.0)$ & & $39.2(14.5)$ & \\
\hline $11-20(n=309)$ & $46.4(17.6)$ & & $40.9(17.7)$ & & $24.2(19.3)$ & & $37.4(16.0)$ & \\
\hline$>20(n=442)$ & $43.4(17.9)$ & & $39.0(18.4)$ & & $24.2(19.1)$ & & $35.7(16.3)$ & \\
\hline Workload (h/week) & & & & & & & & \\
\hline$\leq 40(n=204)$ & $43.9(15.8)$ & & $39.7(17.2)$ & & $27.2(19.9)$ & & $37.1(15.3)$ & \\
\hline $41-60(n=744)$ & $46.6(17.0)$ & חم2 ח & $41.2(17.0)$ & 6 & $24.9(18.9)$ & >0 & $37.7(15.3)$ & קח ? \\
\hline $61-80(n=314)$ & $46.4(17.5)$ & 0.200 & $41.6(17.6)$ & 0.011 & $24.0(18.6)$ & 0.200 & $37.6(15.6)$ & 0.002 \\
\hline$>80(n=77)$ & $46.3(20.1)$ & & $40.8(20.0)$ & & $25.9(21.6)$ & & $37.8(18.4)$ & \\
\hline
\end{tabular}


As is described in Table 3, results showed that women present significantly higher burnout, as well as younger physicians and more recent specialists.

\section{DISCUSSION}

The current study tested the factor structure of $\mathrm{CBI}$ in which a latent $2^{\text {nd }}$ order factor was created, allowing for a global burnout score that results from the sum of the total items' scores in CBI. Our results support that this index potentially useful for its communicative simplicity - is a valid way to explore data and discuss results from studies on burnout.

The confirmatory factor analyses showed that both the 3-factor and the 1-factor ( $2^{\text {nd }}$ order structure) presented good model fit, and therefore CBI can be interpreted based on these two different structures depending on the specific research question at hand. Nevertheless, it is worth noting that the 1-factor model presented significantly better model fit than the 3-factor model, which suggests that using the global burnout score is not only suitable but actually preferable. To our knowledge, this is the first study that has presented a reliable structure to measure a global burnout index in physicians, and the first to compare this structure with a 3-factor structure.

The endeavour to achieve a global burnout index has already been pursued in a sample of students, ${ }^{10}$ but the global index resulted from three different burnout scales (CBI, MBI, and Oldenburg Burnout Inventory). Although this was a valuable effort, to use this index would imply using a large number of items that derive from different conceptualizations of burnout. In fact, some authors suggest that dimensions in $\mathrm{MBI}$ (depersonalization and personal accomplishment) do not measure burnout. ${ }^{7,8}$

Our results from reliability analyses showed that $C B I$ (both its 3-factor and global factor structures) presented good internal consistency. These results are aligned with other studies from different populations, such as Taiwan employees, ${ }^{9}$ Chinese Human Service workers, ${ }^{27}$ and Australian dentists. ${ }^{28}$ Results from the average variance extracted showed that the three subscales presented good discriminant validity, except between the personal and workrelated subscales. This can suggest that some aspects that underlie personal-related burnout are associated with workrelated ones.

Correlation analyses showed that $\mathrm{CBI}$ presented good criterion validity in our sample, as all three subscales as well as its global burnout index were positively correlated with psychopathological symptoms and rumination, and negatively associated with satisfaction with life. This is in line with previous studies that associate depression and stress with burnout, ${ }^{29}$ and show its detrimental impact on satisfaction with life. ${ }^{30}$ Indeed, although the relationship between burnout and rumination has not been extensively explored in previous studies, the association between depression and burnout is well-known, as well as the impact of rumination on depressive symptoms. ${ }^{21}$

Additionally, a significant difference was found in burnout (both 3-factor and 1-factor) in gender (women presented higher burnout than men) and in age (younger physicians presented more burnout).

Interestingly enough, no differences were found in patient-related burnout. Further studies should address this and explore underlying reasons for this result. Also, differences were found in personal-related burnout according to institution of practice, in which those who practice exclusively in the public health sector presented more burnout that those practicing in the private sector or both. Interestingly, no differences were found according to workload. One possible way of making sense of these results is by assuming that burnout has more to do with personal variables, such as emotional regulation skills and social support. However, we advise great caution with drawing definite conclusions, as we should consider the different sample sizes of each group.

Some limitations should be considered when these results are interpreted. The cross-sectional nature of the design prevents us from drawing conclusions regarding causality between variables. This is particularly relevant when interpreting results from correlational analyses. Additionally, the current study did not explore temporal stability of the measure, which is an important factor when asserting validity. Future studies should conduct temporal stability analyses following a longitudinal design, as well as normative studies in a representative sample. Finally, the assessment was conducted using self-reported measures, which do not account for social desirability. One possible way of controlling this would be by conducting a burnout semi-structured clinical interview, which would allow a more nuanced exploration of burnout factors.

\section{CONCLUSION}

In conclusion, the current paper provides evidence for the feasibility of using $\mathrm{CBI}$ as a 1-factor measure, which allows clinicians and researchers to attain a single straightforward global burnout index. This will allow for future studies to more thoroughly explore burnout in different occupations, as well as developing population-based cut-offs for clinically meaningful levels of burnout. Additionally, our results provided evidence for the validity of $\mathrm{CBI}$ as a robust measure of burnout related to the physician, the work itself and the patient. Even though an assessment of different areas in which burnout arise (personal, work, patient) provides an understanding of the different routes that lead to burnout, a 1-factor index allows us the best of both worlds. The use of a global measure provides a clear and easily obtainable assessment of the degree of the professional burnout. This global index can then be further analyzed in detail through the three dimensions, and specific strategies to prevent further burnout can be implemented according to the more salient dimension.

\section{ACKNOWLEDGMENTS}

Authors would like to thank all participants included in the current study. 


\section{CONFLICTS OF INTEREST}

Authors declare there are no conflicts of interest.

\section{FINANCIAL SUPPORT AND SPONSORSHIP}

The current study was developed without financial support.

\section{REFERENCES}

1. Dyrbye LN, Sotile W, Boone S, West CP, Tan L, Satele D, et al. A survey of U.S. physicians and their partners regarding the impact of work-home conflict. J Gen Intern Med. 2014;29:155-61.

2. Hawton K, Clements A, Sakarovitch C, Simkin S, Deeks JJ. Suicide in doctors: a study of risk according to gender, seniority and specialty in medical practitioners in England and Wales, 1979-1995. J Epidemiol Community Health. 2001;55:296-300.

3. Shanafelt TD, Hasan O, Dyrbye LN, Sinsky C, Satele D, Sloan J, et al. Changes in burnout and satisfaction with work-life balance in physicians and the general US working population between 2011 and 2014. Mayo Clin Proc. 2015;90:1600-13.

4. Wallace JE, Lemaire JB, Ghali WA. Physician wellness: a missing quality indicator. Lancet. 2009;374:1714-21.

5. Marôco J, Marôco AL, Leite E, Bastos C, Vazão MJ, Campos J. Burnout in Portuguese healthcare professionals: an analysis at the national level. Acta Med Port. 2016;29:24-30.

6. Maslach C, Jackson SE, Leiter MP. Maslach Burnout Inventory. In: Zalaquett CP, Wood RJ, eds. Evaluating stress: a book of resources. Lanham: The Scarecrow Press, Inc.; 1986. p.191-18.

7. Kristensen TS, Borritz M, Villadsen E, Christensen KB. The Copenhagen Burnout Inventory: a new tool for the assessment of burnout. Work Stress. 2005;19:192-207.

8. Borritz M, Rugulies R, Bjorner JB, Villadsen E, Mikkelsen OA, Kristensen TS. Burnout among employees in human service work: design and baseline findings of the PUMA study. Scand J Public Health. 2006;34:49-58.

9. Yeh WY, Cheng Y, Chen CJ, Hu PY, Kristensen TS. Psychometric properties of the chinese version of copenhagen burnout inventory among employees in two companies in Taiwan. Int $\mathrm{J}$ Behav Med. 2007; 14:126-33.

10. Marôco J, Bonini Campos JA. Defining the student burnout construct: a structural analysis from three burnout inventories 1. Psychol Rep. 2012;111:814-30.

11. Milfont TL, Denny S, Ameratunga S, Robinson E, Merry S. Burnout and wellbeing: testing the Copenhagen Burnout Inventory in New Zealand teachers. Soc Indic Res. 2008;89:169-77.

12. Fonte $\mathrm{CM}$. Adaptação e validação para português do questionário de Copenhagen Burnout Inventory (CBI). [tese de mestrado]. Coimbra: Faculdade de Economia, Universidade de Coimbra; 2011.

13. Lovibond PF, Lovibond $\mathrm{SH}$. The structure of negative emotional states: comparison of the Depression Anxiety Stress Scales (DASS)

\section{PROTECTION OF HUMANS AND ANIMALS}

The authors declare that the procedures were followed according to the regulations established by the Clinical Research and Ethics Committee and to the Helsinki Declaration of the World Medical Association.

\section{DATA CONFIDENTIALITY}

The authors declare having followed the protocols in use at their working center regarding patients' data publication.

with the Beck Depression and Anxiety Inventories. Behav Res Ther. 1995;33:335-43.

14. Ribeiro JL, Honrado AA, Leal IP. Contribution to the adaptation study of the Portuguese Adaptation of the Lovibond and Lovibond Depression Anxiety Stress Scales (EADS) with 21 items. Psicol Saude Doenças. 2004:2229-39.

15. Diener E, Emmons RA, Larsen RJ, Griffin S. The satisfaction with life scale. J Pers Assess. 1985;49:71-5.

16. Simões A. Ulterior validação de uma escala de satisfação com a vida (SWLS). Rev Port Pedagog. 1992;26:503-15.

17. Sheehan DV. Sheehan disability scale. Handb Psychiatr Meas. 1983:113-5.

18. Gouveia JP. Ansiedade social: da timidez à fobia social. Vol Saúde \& So. Coimbra: Quarteto E.; 2000.

19. Treynor W, Gonzalez R, Nolen-Hoeksema S. Rumination reconsidered: a psychometric analysis. Cognit Ther Res. 2003;27:247-59.

20. Dinis A, Pinto-Gouveia J, Duarte C, Castro T. Estudo de validação da versão portuguesa da Escala de Respostas Ruminativas-versão reduzida. Psychologica. 2011:175-202.

21. Lyubomirsky S, Nolen-Hoeksema S. Self-perpetuating properties of dysphoric rumination. J Pers Soc Psychol. 1993;65:339-49.

22. Hair JF, Anderson RE, Tatham RL, Black WC. Multivariate data analysis New Jersey: Englewood Cliff; 1998.

23. Diamantopoulos A, Siguaw JA, Siguaw JA. Introducing LISREL: a guide for the uninitiated. Newbury Park: Sage; 2000.

24. Bollen KA. Structural equations with latent variables. Hoboken: John Wiley \& Sons, Inc.; 1989.

25. Tabachnick BG, Fidell LS. Using multivariate statistics. $5^{\text {th }}$ ed. Boston: Allynand Bacon; 2007.

26. Hu L, Bentler PM. Fit indices in covariance structure modeling: sensitivity to underparameterized model misspecification. Psychol Methods. 1998;3:424.

27. Fong TC, Ho RT, Ng SM. Psychometric properties of the copenhagen burnout inventory-Chinese version. J Psychol. 2014;148:255-66.

28. Winwood PC, Winefield AH. Comparing two measures of burnout among dentists in Australia. Int J Stress Manag. 2004;11:282.

29. Košir K, Tement S, Licardo M, Habe K. Two sides of the same coin? The role of rumination and reflection in elementary school teachers' classroom stress and burnout. Teach Teach Educ. 2015;47:131-41.

30. Senter A, Morgan RD, Serna-McDonald C, Bewley M. Correctional psychologist burnout, job satisfaction, and life satisfaction. Psychol Serv. 2010;7:190. 